\title{
Instructional Needs Analysis and Cultural Values in Online Learning
}

\author{
Nadia Hanoum ${ }^{1}$ \\ Hana Silvana ${ }^{2}$ \\ Department of Curriculum and Educational Technology, Universitas Pendidikan Indonesia, \\ Bandung, Indonesia \\ ${ }^{1}$ nadia.hanum@upi.edu \\ ²hanasilva@upi.edu
}

First draft received: 15 May 2019 Date Accepted: 18 Jun 2019 Final proof received: 31 Aug 2019

\begin{tabular}{l} 
Abstract \\
In online learning, learners are not allowed to have face to face and direct interaction with their teacher and \\
their peers. Consequently, they have to be independent from their teacher in learning. From a cultural \\
perspective, the nature of online learning is related to learners' high individualism and low power distance \\
between students and instructor, which is contradictory with Indonesian cultural values of high collectivism \\
and high power distance. This study aimed to analyze the cultural values and online learning preferences \\
of Indonesian students, identify the cultural issues resulted from the values and preferences, and \\
determine the instructional strategies that could meet their learning needs so that learning effectiveness \\
could be improved. This study employed a quantitative descriptive method and a questionnaire was used \\
as the instrument to gather data from a group of students who took online learning via Integrated Online \\
Learning System (Indonesian, SPOT) learning management system. The results suggested that \\
Indonesian students exhibited high power distance and low tolerance for uncertainty and were culturally \\
more collectivist and feminine. These cultural values affected the process of online learning in three \\
different areas, namely assessment, instruction, and communication. Thus, a set of instructional strategies \\
were proposed to overcome the problems posed by the learning culture of Indonesian students so that \\
online learning could be more effective. \\
Keywords: Cultural values, instructional needs, online learning \\
\hline \hline \\
To cite this paper (in APA style): \\
Hanoum, N., \& Silvana, H. (2019). Instructional needs analysis and cultural values in online learning. \\
International Journal of Education, 12(1), 9-15. doi: 10.17509/ije.v12i1.17776 \\
\hline
\end{tabular}

\section{INTRODUCTION}

Unlike face-to-face learning, online learning eliminates teacher physical presence, which makes learning centered on students, put more attention on assessment and focus more on collective knowledge construction. (Darmayanti, 2007; Anderson, 2008). Consequently, students need to adapt their attitude and behavior to the nature of online learning which may not be compatible with their cultural values. Ess (2009, p. 20) pinpoints this problem by stating that "online learning technologies and techniques grounded in one culture will likewise reflect the cultural values and communicative preferences of that culture;" therefore, "when taken up by students in cultures shaped by different assumptions and values, such implementations generally fail." Since online learning is grounded in the western world view, certain adaptation should be made to accommodate learners coming from non-western countries (Liu, et al., 2010).

Different cultures possess different cognitive styles (Anderson, 1988). Cognitive style refers to a learner's preferences in processing information, and one of its dimensions that affect the process of online learning is the differences between field-dependent and field-independent personalities (Witkin, Moore,
Goodenough, \& Cox, 1977 in Ally, 2008). Fielddependent students are more motivated by external supports such as instructor guidance and group work, while field-independents are internally motivated and prefer to learn on their own (Witkin, 1977 in Sanchez and Gunawardena, 1998). Given that online learning requires learners to be able to study without instructor's physical presence which means limited instructor guidance, it is no surprise that learners with field-independent personalities coming from western societies or who hold western cultural values more easily adopt online learning because the design is based on western cognitive styles.

The differences between field-independent and field-dependent students have been studied by several researchers. Sanchez and Gunawardena (1998) reveal that Hispanic learners are fielddependent and collectivist, which are the characters of non-western cognitive styles. Consequently, they demonstrate a strong need for feedback from the instructor and prefer collaborative to competitive activities. Blanchard, Razaki, and Frasson (2005) report that while Canadian and French learners are individualistic, Brazilians and Iranians are relatively collectivist. Individualistic learners thus prefer to work 
alone than in a group and collectivist learners otherwise. In addition, Liu et al. (2016) believe that learners from countries with higher individualism and lower power distance (Australia, Canada, USA, UK) are more likely to complete all the online learning activities (viewed video and solved quizzes) and place a higher value on dialogue and discussion in the learning process. On the other hand, learners from countries with lower individualism and higher power distance (China, India, Singapore) are more prone to focus on assessment (quizzes) and exhibit less participation in discussion forum.

The impact of cultural preferences on online learning has been observed in eastern countries such as Iran, China, and Indonesia. Zhang (2007) suggests that in China the online learning focuses more on the course materials and pays minimum attention to learning support and services. As a result, learners cannot get the help and guidance they need from the instructor and are not motivated to participate in learning activities. In the same line, Masoumi (2010) reports that in Iran the implementation of online learning is based on instructivist principles characterized by instructor's domination, learners' high preference for extrinsic motivation, and lack of learner control in the learning process. In Indonesia, Sulistyo-Basuki (2007) believes that the cultural factor that impedes the adoption and implementation of online learning is the preference for the oral tradition over the writing, which explains why Indonesian learners prefer to communicate or interact directly with instructors and other learners than to communicate via the internet as required in an online learning environment. The same finding was also reported by Silvana \& Hanoum (2016) who researched the implementation of MOOCs based elearning system in the higher education context. The study reveals that the online learning system built lacks interactivity, which is indicated by low learners' participation in the discussion forum. This finding suggests that learners are not convenient to communicate in writing due to the rooted oral tradition culture.

In the final analysis, learners from eastern cultures expect online learning to be teacherdominated (strong need to interact with instructor), are more dependent on social reinforcement (more collectivist), are more in favor of oral synchronous communication, and put a higher value on test scores instead of knowledge construction. Therefore, to ensure the effectiveness of online learning in the context of eastern education, several instructional strategies need to be incorporated into online learning activities. Hence, this research aimed to analyze Indonesian learners' cultural preferences in learning and their learning behaviors in an online learning environment, identify the cultural issues that could strongly affect learning effectiveness, and determine the critical adaptations that should be applied to the instructional design to overcome the issues.

\section{METHODS}

This research was designed as a descriptivequantitative study in the interest of obtaining databased results and comprehensive analysis on students' cultural values in online learning to devise instructional design compatible with the culture. The data for this research was collected in October 2018 from a group of students taking a course via the Integrated Online Learning System (Indonesian, SPOT) of Universitas Pendidikan Indonesia (UPI). With a cluster sampling technique based on convenience, a total of 32 respondents were selected, consisting of 19 and 13 female and male students, respectively. The students were from the Faculty of Educational sciences and were in their second year, enrolling in an online course,

The questionnaire used consisted of 20 closeended questions with a four-point Likert scale, divided into two parts. The first part, which was adapted from Hofstede (1980 in Hofstede, 2011), aimed to gain insight into students' cultural preferences in learning. The second part, which was adapted from Liu, et al. (2010), was intended to see students' online learning pattern in the aspects of assessment, interaction, communication, and collaboration. Before the questionnaire was distributed, the respondents were asked for their consent and were informed that their responses would be kept confidential. The collected data was analyzed using descriptive statistics, in which responses were presented in percentage.

\section{RESULTS AND DISCUSSION}

This section first presents the results of students' cultural preferences in learning and students' behavior in online learning. The results are then discussed in depth to understand how the cultural preferences affect the main aspects of online learning and provide some instructional strategies that can be used to help students learn effectively in an online learning environment.

\section{Results}

The process of online learning requires learners to study independently and exhibit high motivation in learning although they cannot have face-to-face interaction with their teachers and their peers. From a cultural perspective, the nature of online learning is more compatible with low power distance culture and high individualism. Given that Indonesian people tend to show high power distance and low individualism, online learning is not compatible with Indonesian culture. Consequently, certain instructional design is needed to overcome the compatibility problem.

Before formulating an instructional design that can meet students' instructional needs in online learning, it is necessary to analyze students' preferences regarding cultural dimensions that can greatly influence the process of online learning. The term cultural dimension was first coined by Hofstede (1980 in Hofstede, 2011) who conceptualized it in four dimensions: (1) Power distance: To accept or not accept equal distribution of power; (2) Uncertainty avoidance: To feel comfortable or uncomfortable with uncertainty and ambiguity; (3) Individualism versus collectivism: To prefer individual responsibility or group responsibility; (4) Masculinity versus femininity: Degree of preference for achievement, competition and material success. The four dimensions were then added with two other dimensions: long-term versus 
short-term orientation (related to people's efforts) and indulgence versus restrain (related to enjoying life).

However, Leidner and Kayworth (2006) contended that out of the six cultural dimensions, only power distance, uncertainty avoidance, masculinityfemininity, and collectivism that impact the adoption of online learning. Parris and Linder-VanBerschot (2010) also include the four cultural dimensions into their cultural dimensions of learning framework, divided into three categories: social relationships, epistemological beliefs, and temporal perceptions.
Power distance (equality vs. authority), individualism vs. collectivism, and masculinity-femininity (challenge vs. nurture) dimensions fall into social relationships category, while uncertainty avoidance (stabilityseeking vs. uncertainty-acceptance) falls into epistemological beliefs category. The students' preferences on the four cultural dimensions are presented in Table 1.

Table 1. Students' Cultural Preferences in Learning

\begin{tabular}{|c|c|c|}
\hline $\begin{array}{l}\text { Cultural } \\
\text { Dimension }\end{array}$ & Statement & Percentage \\
\hline \multirow{3}{*}{$\begin{array}{l}\text { Power } \\
\text { Distance }\end{array}$} & Instructor and students have an equal position. (No superiority or inferiority) & $20 \%$ \\
\hline & Students have bigger responsibility than instructor in the learning process. & $25 \%$ \\
\hline & Dialogue and discussion are important parts of the learning process. & $40 \%$ \\
\hline \multirow{3}{*}{ Individualism } & Acting as an independent individual is an important thing for me. & $40 \%$ \\
\hline & $\begin{array}{l}\text { Learning how to learn (cognitive skills) is the most important thing. } \\
\text { (individual development) }\end{array}$ & $35 \%$ \\
\hline & $\begin{array}{l}\text { Learning how to do (content knowledge) is the most important thing (social } \\
\text { development) }\end{array}$ & $45 \%$ \\
\hline \multirow{2}{*}{ Masculinity } & I am a competitive person. & $32 \%$ \\
\hline & Collaboration is more important than competition. & $70 \%$ \\
\hline \multirow{2}{*}{$\begin{array}{l}\text { Uncertainty } \\
\text { Avoidance }\end{array}$} & Getting correct answers is more important than the thinking process. & $65 \%$ \\
\hline & $\begin{array}{l}\text { I am looking for other resources besides what have been recommended by } \\
\text { the instructor. }\end{array}$ & $30 \%$ \\
\hline
\end{tabular}

Table 1 shows that for power distance, 20 percent of the students agreed that instructor and students should have an equal position. In addition, the majority of students (75 percent) still held the view that the instructor had more responsibility for the success of their learning. This result indicated that students were so dependent on their instructor that during the learning process the instructor dominated the interaction. In consequence, students also admitted they did not feel the need to be involved in dialogues or discussions as essential parts in the learning process (40 percent). All in all, there was a high power distance between the instructor and the students, in which the students considered the instructor to be more powerful, and thus it was acceptable to be dependent on the instructor.

In the case of individualism, the data indicates that students exhibited low individualism. Only 40 percent of students agreed that acting as independent individual was an important principle. This is closely related to the number of students who viewed that social development was the most important aspect in learning (55 percent), compared to those who viewed individual growth as the most important (35\%). In other words, the students were more collectivist and thus had a strong affinity with their group.
With regard to masculinity, there were about 32 percent of students who thought of themselves as a competitive person or who enjoyed competitive atmosphere. Additionally, the majority of students (70 percent) preferred collaboration to competition. These results imply that the students did not like a competition in learning, and therefore were not encouraged to obtain individual achievement because having collaboration was more comfortable. As for uncertainty avoidance, the data suggests that the students expected assurance in learning and avoided doing activities offering uncertain results. These preferences can be seen from the number of students who believed that getting the correct answer was more important than the thinking process needed (65 percent). Furthermore, most students only used books recommended by the instructor and only 30 percent of students had the initiative to search for other resources in addition to what was recommended by the instructor.

The above cultural values affected the online learning process, especially in the aspect of assessment, interaction, and communication. Students' preferences in those three aspects are described below. 
Table 2. Students' Online Learning Preferences

\begin{tabular}{lll}
\hline $\begin{array}{c}\text { Aspects of } \\
\text { Learning }\end{array}$ & \multicolumn{1}{c}{ Activities } & Percentage \\
\hline \multirow{3}{*}{ Assessment } & I took all the quizzes. & $96 \%$ \\
\cline { 2 - 3 } & I did all the reading assignments. & $48 \%$ \\
\cline { 2 - 3 } & I had discussion with friends when taking the quizzes. & $96 \%$ \\
\cline { 2 - 3 } Interaction & $\begin{array}{l}\text { I watched all the learning videos suggested. } \\
\text { I looked for additional resources if I couldn't understand the materials } \\
\text { given by the instructor. }\end{array}$ & $90 \%$ \\
\cline { 2 - 3 } & $\begin{array}{l}\text { The online learning system encouraged me to actively learn the materials } \\
\text { given so I could understand them without the instructor's help. }\end{array}$ & $56 \%$ \\
\hline \multirow{2}{*}{ Communication } & $\begin{array}{l}\text { I preferred asking question directly to the instructor instead of via online } \\
\text { forum or email. }\end{array}$ & $76 \%$ \\
\cline { 2 - 3 } & I preferred independent online learning to face-to-face meeting. & $20 \%$ \\
\hline
\end{tabular}

In terms of assessment, the majority of students (90 percent) took the quiz but only less than half of the total students (48 percent) did the reading assignments, indicating that the students put more priority in getting the right answer and did not give the thinking process conducted through reading activities the same priority. Furthermore, most students (96 percent) also had discussions with friends when taking quizzes, which indicated that they had high collectivism. As for learning activities, more than half of the students (60 percent) watched all the learning videos and the rest (40 percent) did not watch the videos although it could help them understand the materials better. Almost all students (92 percent) downloaded all the learning materials provided and looked for additional resources (96 percent) but only 52 percent of them actively studied the acquired materials. In communication process, the majority of students (76 percent) preferred to ask questions directly offline instead of online and consequently there was only a small number of students (20 percent) who favored online learning.

\section{Discussion}

The high gap between instructor and students results from the large power distance in which there is imbalance of power distribution that leads students to see their instructor as a superior person who should be reliable in assisting during the learning process. Thus, as subordinates, students expect to be told of what to do (Hofsted, 2011). The students become so dependent on directions and instructions from the instructor in learning, making it difficult for them to be independent learners who take responsibility for their own learning. As a result, the effectiveness of online learning is greatly affected. This dependency can be seen from students' learning activities, in which only 52 percent of them actively studied the materials on their own without feeling the need to have face-to-face interaction with the instructor. Furthermore, the number of students who favored online learning is very small (20 percent), which indicates students' tendencies to put the instructor as the most responsible person for their learning success instead of themselves.

Students' collectivist culture is highlighted by their dependency on their groups, even when they are required to work individually. This was shown when they took quizzes, where almost all students (96 percent) did the quizzes in groups so they could discuss the answers. If they did not know the answer, they were not worried because they could get the answer from their friends. Their friends were willing to give them the answers because in a collectivist culture, harmony should always be maintained and relationship prevails over task (Hofsted, 2011). Therefore, although the instructor required them to work individually, they did not abide by the rule because if they did not cooperate with their friends, the harmony and relationship among them would be disturbed.

Moreover, preferences for content knowledge instead of cognitive skills suggest that they considered social development more important than individual development (Hofsted, 2011). Hence, students depend much on their social environment (teachers and friends) rather than on their own abilities. As argued by Witkin (1977 in Sanchez and Gunawardena, 1998), non-western societies are more field-dependent in which they are more likely to be motivated by external supports such as instructor guidance and group work compared to fieldindependents who are internally motivated and prefer to learn on their own.

This high dependency brings several consequences which will eventually decrease the effectiveness of the learning process. First, they do not feel the need to prepare well for quizzes or exams, especially if the quizzes and the exams are administered online and without supervision. Consequently, their understanding of the materials will not improve, and their score will not be as high as those who study hard. Second, as students rely on their friends to get a good score, they do not feel the urgency to improve or develop as an individual and become diffident on their own abilities to solve problems both in and outside the class.

Masculinity/femininity in learning is manifested in students' tendency toward competition in the class (Hofsted, 2011). The data showed that the majority of the students did not like competition or competitive atmosphere and chose collaboration over competition. This suggests that in the context of learning the students are culturally more feminine. Hofstede (2011) states that in feminine culture, men and women should be modest and caring, which explains why in learning students favor collaboration instead of competition. Unfortunately, unless the collaboration is conducted in groups with a clear assignment for each 
member of the group, it will merely become the occasions where students with stronger academic ability sympathize for the weak by simply telling them the correct answers, even during the test.

The last cultural dimension that strongly influences the learning process is uncertainty avoidance which relates to students' tolerance for uncertainty and ambiguity that happen in learning. The data reveals that the majority of the students exhibited strong uncertainty avoidance, which is indicated by their preference in putting more priority on getting correct answers than on the process that can lead to obtaining the answers. Hofstede (2011) points out that strong uncertainty avoidance societies expect teachers to have all the answers and have strong need for clarity and structure in the learning process. As a result, the communication style favored by most of the students is face-to-face communication although they are in the process of taking online learning. This preference also influenced their participation in the online discussion forum, which is very low (23 percent). Indeed, the nature of online discussion forum is asynchronous and as such, there is no certainty if students' questions will be answered by the instructor and other students and even if answered there is no guarantee that they will be answered immediately. These shortcomings make students unwilling to participate in online forum discussions because they think the forums will be useless and just a waste of time.

A number of instructional strategies have been proposed by many researchers to address the cultural issues presented above so that learners from nonwestern or eastern world get the support needed to succeed in online learning. Sanchez and Gunawardena (1998) recommend the application of a wide variety of instructional strategies to cater for the cultural differences. However, their study did not further suggest in what ways the instructional activities and resources can be organized to integrate learners' cultural values into the instructional system. Nathan (2008) argues that the cultural issues that should be addressed in order to build an effective online learning system include: (1) Individualism versus collectivism, (2) Gender, (3) Relationship of student and instructor, (4) Age and generation, (5) Focus on time, and (6) Inductive versus deductive reasoning. Students' different focus on time, for instance, should be facilitated by giving flexibility in deadlines instead of applying fixed deadlines. In the same vein, Rao (2010) proposes differentiation in online learning methods (synchronous or asynchronous) according to the degree of power distance, degree of uncertainty avoidance, preference for individualism versus collectivism, and preference for short-term versus long-term orientation. For example, learners with high power distance culture expect to learn directly from the instructor and therefore synchronous online learning is more suitable because it allows learners to identify a learning expert to showcase subject knowledge.

On the other hand, Edmundson (2011) proposes that the cultural adaptation of online learning includes content, instructional design, and media. The instructional design employed should be able to facilitate learners' learning styles and cultural characteristics, and the assessment techniques should also align with their cultural preferences. For this purpose, the cultural adaptation process involves: (1) Analyzing learners' cultural learning styles, preferences, and environment; (2) Identifying what cultural issues that could strongly affect learning outcomes; and (3) Determining critical adaptations that should be applied to content, instructional strategies, and media (Edmundson, 2011). As analyzed earlier, the students exhibited high power distance, low individualism (more collectivist), low masculinity (culturally feminine), and high uncertainty avoidance. These preferences affect the process of online learning, especially in the aspects of assessment, interaction, and communication. Each aspect is influenced by different cultural dimensions and is mapped out accordingly along with the resulting instructional needs in Table 3.

Table 3. Students' Cultural Problems and Instructional Needs in Online Learning

\begin{tabular}{|c|c|c|}
\hline Aspect of Learning & Influence of Cultural Dimension & Instructional Needs \\
\hline Assessment & $\begin{array}{l}\text { High collectivism } \rightarrow \text { Students do not } \\
\text { believe in their own abilities in doing the } \\
\text { test, are dependent on friends or group, } \\
\text { prioritize harmonic relationship in group. } \\
\text { Low masculinity (more feminine) } \rightarrow \\
\text { Students exhibit group orientation } \\
\text { behaviors and low motivation for } \\
\text { individual development. }\end{array}$ & $\begin{array}{l}\text { Accommodating process-oriented } \\
\text { assessment method and multiple } \\
\text { assessment methods. }\end{array}$ \\
\hline Interaction & $\begin{array}{l}\text { Large power distance } \rightarrow \\
\text { Students are so dependent on direction } \\
\text { and instruction from the instructor, } \\
\text { possess low autonomy in learning, } \\
\text { cannot self-regulate their learning. }\end{array}$ & $\begin{array}{l}\text { Independent learning and self- } \\
\text { regulated learning skills. }\end{array}$ \\
\hline Communication & $\begin{array}{l}\text { High uncertainty avoidance } \rightarrow \text { Students' } \\
\text { low participation in online discussion } \\
\text { forum due to uncertainty in getting } \\
\text { instructor's or friends' responses and } \\
\text { when they will be responded. }\end{array}$ & $\begin{array}{l}\text { Encouragement or rewards (points } \\
\& \text { badges) for active participation in } \\
\text { forum discussion and the need for } \\
\text { synchronous mode of } \\
\text { communication which enable them } \\
\text { to obtain real time feedback. }\end{array}$ \\
\hline
\end{tabular}


As shown in Table 3, Indonesian students' cultural problems can be tackled by implementing specific instructional strategies that can facilitate them to study effectively within an online learning environment. Firstly, the assessment should employ multiple methods combining both product and processoriented assessments. An ongoing and processoriented assessment allows for students' continuous involvement and application of the theories (Liu, et al., 2010). Process-oriented assessments can be in the forms of observation, problem-solving activities, reflective journals, portfolio assessment, and assignments or homework.

The interaction between students and instructor should promote independent learning and foster selfregulated learning skills. Studies found that selfregulated learning behaviors correlated positively with academic achievement (Littlejohn, Hood, Milligan, \& Mustain, 2016). Self-regulated learning skills utilize students' ability to initiate metacognitive, cognitive, affective, motivational, and behavioral processes needed to achieve learning goals successfully (Kizilcec, Perez-Sanagustin, \& Maldonado, 2016). Self-regulated learning skills include goal-setting, selfefficacy, learning and task strategies, and helpseeking strategies (Littlejohn, Hood, Milligan, \& Mustain, 2016). These skills will empower the students so that they are willing to take responsibility for their own learning. Once they do, they will be more motivated and will not be highly dependent on their instructor.

The communication should be more intensified and varied to increase students' low participation in discussions. Students' participation in forum discussions can be boosted by giving points and badges as rewards. Awarding points is effective in increasing intrinsic motivation, as it provides instant feedback and recognition for the completion of an activity or task (Lister, 2015). Badges embedded in a system encourage learners to keep interacting with the system or to take part in some learning activities and to finally achieve the learning goal (Yang, Quadir, and Chen, 2016). Badges can also be used to display students' achievement and allow students to achieve social recognition which will improve their motivation and engagement (Lister, 2015).

Asynchronous modes of communication should be varied with synchronous ones which allow for immediate responses and thus greatly reduce the possibilities of being in uncertainties. As argued by Liu et al., (2010), using both types of communication modes can balance the weaknesses of each mode. While synchronous communication provides live interaction, it requires timely participation. Conversely, asynchronous communication offers flexibility, but it is unable to convey the nuances of human interaction due to delayed text-based communication. Thus, the balanced use of both modes is recommended.

\section{CONCLUSIONS}

The process of online learning requires learners to study independently and exhibit high motivation in learning although they cannot have face-to-face interaction with their teachers and their peers. From a cultural perspective, the nature of online learning is more compatible with low power distance culture and high individualism. Given that Indonesian people tend to show high power distance and low individualism, online learning is not compatible with Indonesian culture. Consequently, certain instructional design is needed to overcome the compatibility problem.

First, large power distance affects the interaction in the classroom, where students become too dependent on the instructor. Therefore, the instructor should promote learning autonomy and self-regulated learning skills through various methods and learning activities. Second, high collectivism influences the assessment process, as it makes students diffident on their own abilities and highly dependent on friends or their group. Consequently, multiple assessment methods should be used to make the students believe in their abilities and eliminate dependency on their group.

Students' high uncertainty avoidance hampers the communication process because online discussion forum does not provide real-time feedback. Thus, synchronous communication mode such as mobile messengers or social media can be added to smooth the communication. Finally, high femininity lowers students' motivation to compete due to prioritization on the group's harmony and relationship among the group's members. Hence, creating fun competition through gamification is paramount, as it encourages them to compete with their friends without harming the group's harmony.

\section{REFERENCES}

Ally, M. (2008). Foundations of educational theory for online learning. In T. Anderson, (Ed.), The theory and practice of online learning (pp.17-44). Canada: AU Press.

Anderson, J. A. (1988). Cognitive styles and multicultural populations. Journal of Teacher Education, 39(1): 2-9. Retrieved from http://journals.sagepub.com/doi/pdf/10.1177/002 248718803900102

Anderson, T. (2008). Towards a theory of online learning. In T. Anderson, (Ed.), The theory and practice of online learning (pp. 45-74). Canada: AU Press.

Blanchard, E., Razaki, R., Frasson, C. (2005). Cross-cultural adaptation of e-learning contents: A Methodology. International Conference on ELearning, Vancouver, Canada.

Chen, J. C. (2013). Opportunities and challenges of MOOCS: Perspectives from Asia. Paper presented at IFLA WLIC. Retrieved from: http://library.ifla.org/157/1/098-chen-en.pdf

Darmayanti, T. Setiani, M. Y., \& Oetojo, B. (2007). Elearning pada pendidikan jarak jauh: Konsep yang mengubah metode pembelajaran di perguruan tinggi di Indonesia. Jurnal Pendidikan Terbuka dan Jarak Jauh, 8(2), 99-113. Retrieved from http://simpen.lppm.ut.ac.id/ptij/PTJJ\%20Vol\%20 8.2\%20september\%202007/02-

Edmundson, A. L. (2011). The cultural adaptation of e-learning: using appropriate content, instructional design, and media. In Cases on globalized and culturally appropriate e-learning (pp. 308-325). New York: eWorld Learning. doi: 10.4018/978-1-61520-989-7.ch016

Ess, C. (2009). When the solution becomes the problem: Cultures and individuals as obstacles 
to online learning. In R. Goodfellow and M. Lamy (Eds.), Learning cultures in online education (pp. 15-29). Norfolk, Great Britain: Continuum International Publishing Group.

Hofstede, G. (2011). Dimensionalizing cultures: The Hofstede model in context. Online Readings in Psychology and Culture, 2(1), 8. doi:10.9707/2307-0919.1014

Jung, I. (2014). Cultural influences on online learning. In I. Jung \& C. N. Gunawardena (Eds.), Culture and online learning: Global perspective and research (pp. 15-24). Sterling, VA, United States: Stylus Publishing.

Kizilcec, R. F., Perez-Sanagustin M. \& Maldonado J.J. (2016). Self-regulated learning strategies predict learner behavior and goal attainment in massive open online courses. Computers \& Education, 104, 18-33. doi: 10.1016/j.compedu.2016.10.001

Leidner, D. E. \& Kayworth, T. (2006). A review of culture in information systems research: Toward a theory of information technology culture conflict. MIS Quarterly, 30(2), 357-399. Retrieved from https://pdfs.semanticscholar.org/6b8f/e767239a3 4e25e71e99bd8b8a64f8279d7f4.pdf

Lister, M. C. (2015). Gamification: The effect on student motivation and performance at the postsecondary level. Issues and Trends in Educational Technology, 3(2), 1-22. Retrieved from https://journals.uair.arizona.edu/index.php /itet/article/view/18661/18410

Littlejohn, A., Hood, N., Milligan, C., \& Mustain, P. (2016). Learning in MOOCs: Motivations and self-regulated learning. The Internet and Higher Education, 29, 40-48. Retrieved from http://www.sciencedirect.com/ science/article/ pii/ S1096751615300099

Liu, X., Liu, S., Lee, S-h. \& Magjuka, R.J. (2010). Cultural differences in online learning: international student perceptions. Educational Technology \& Society, 13(3), 177-188. http://www.ifets.info/journals/13 3/16.pdf

Liu, Z., Brown, R., Lynch, C. F., Barnes, T., Baker, R., Bergner, Y., \& McNamara, D. (2016). MOOC learner behaviors by country and culture; an exploratory analysis. Proceedings of the 9th International Conference on Educational Data Mining. Retrieved from http://www.upenn.edu/learninganalytics/ryanbak er/paper121.pdf

Masoumi, D. (2010). Quality in E-learning within a cultural context: The case of Iran (Doctoral dissertation). Göteborg, Sweden: University of Gothenburg, Acta Universitatis Gothoburgensis Retrieved

from https://gupea.ub.gu.se/bitstream/2077/22173/1/g upea 207722173 1.pdf

Nathan, E. P. (2008), Global organizations and elearning: Leveraging adult learning in different cultures. Perf. Improv, 47, 18-24. doi:10.1002/pfi.20004

Parrish, P. \& Linder-VanBerschot, J. A. (2010). Cultural dimensions of learning: Addressing the challenges of multicultural instruction. The International Review of Research in Open and Distributed Learning, 11(2), 1-19. Retrieved from http://www.irrodl.org/index.php/irrodl/article/view/ 809/1497

Margayan, A., Bianco, M., \& Littlejohn, A. (2015). Instructional quality of Massive Open Online Courses (MOOCs). Computers and Education, 80, 77-83. Retrieved from: http://www. sciencedirect.com/science/article/pii/S03601315 1400178X $\mathrm{cb} /$

Rao, P. (2010). E-learning in India - The role of national culture and practical implications. Multicultural Education \& Technology Journal, 5(2), 129-150. Retrieved from http://ceurws.org/Vol-570/paper010.pdf

Sanchez, I., \& Gunawardena, C. N. (1998). Understanding and supporting the culturally diverse distance learner. In C. C. Gibson, (Ed.), Distance Learners in higher education (pp. 4764). Madison, WI: Atwood. Retrieved from http://citeseerx.ist.psu.edu/viewdoc/download.doi $=10.1 \cdot 1.452 .5331 \&$ rep $=$ rep $1 \&$ type $=$ pdf

Silvana, H. \& Hanoum, N. (2017). The implementation of Massive Open Online Courses (MOOCs) based e-learning system for college level learners. Comtech Journal, 8(2), 95-100.

Sulistyo-Basuki, L. (2007). IT and education, the case study of e-learning in Indonesia. Paper presented in Korea-ASEAN Academic Conference on Information Revolution and Cultural Integration in East Asia, Ho Chi Minh city, Vietnam, January 25-26, 2007. (In Press) [Conference paper]. Retrieved from http://eprints.rclis.org/9048/1/E-learning_Vietnam - 2007.pdf

Zhang, J. (2007). A cultural look at information and communication technologies in Eastern education. Education Tech Research Dev, 55, 301-314. doi: 10.1007/s11423-007-9040-y

Yang, J.C., Quadir, B. \& Chen, N. (2016). Effects of the badge mechanism on self-efficacy and learning performance in a game-based English learning environment. Journal of Educational Computing Research, 54(3), 371-394. Retrieved from https://journals.sagepub.com/doi/pdf/10.1177/07 35633115620433 